\title{
The Paradox of Being a Probationer: Tales of Joy and Sorrow
}

\author{
Jose F. Cuevas Jr. \\ Misamis University, College of Criminology \\ H. T. Feliciano St. Aguada, Ozamiz City, Philippines
}

\begin{abstract}
Probation is a form of community-based correction; once the probationers are released from jail, they face paradoxical challenges to their personal and social life. This study investigated the paradoxical facets of being a probationer during their probation period. Through purposive sampling, the study identified 17 probationers from Ozamiz City who participated in an in-depth interview and focus group discussion using researcher-made guide questions. The responses were transcribed and analyzed using Colaizzi's descriptive phenomenology. Four central themes emerged from joy and another three from sorrow, a namely new lease on life and freedom, friendship and camaraderie with coprobationers, love, and support of family, acceptance and understanding of community and co-workers. While for the sorrow, the themes of the stigma of being a probationer, traumatization of children/family, insecurity and anxiety. The findings asserted that the attachment to their families and other support system is most important in facing hard challenges. With this, the researcher encouraged the probationers through the supervision of the probation officers to strengthen the family ties and other support systems, which will contribute to the overall process of probationers' rehabilitation and reformation.
\end{abstract}

Keywords:- Community-Based Correction, Phenomenology, Probation, Probationer, Support System.

\section{INTRODUCTION}

Probation is an alternative form of punishment, allowing the convicted person to remain in the community to serve his sentence with conditions set by the court. It is a form of community-based correction, wherein the convicted person has a privilege granted by the court to serve his sentence outside the jail or prison. Once the probationers are released from jail, they face various challenges which affect their personal and social life (Boehm, 2013; Archambeau, 2011). These challenges may serve as either a pathway to desist re-offending, and total reformation, or these may push the probationers to violate their probation supervision and commit another crime. The experiences of living with their family and community are vital elements in their individualized community-based treatment. Prior researches confirmed that the presence of positive and negative environments, including the family, friends, employment, and the community in general, are essential predictors in the rehabilitation and reformation of the probationers (Sump, 2016; Spohr, Suzuki, Marshall, Taxman, \& Walters 2016). Their personal and social experiences are identified as triggering circumstances that can lead to their successful rehabilitation and reformation or failure and revocation of their probation grants (Capece, 2018); Sandoval, 2020). As mentioned in the various studies, it is important to satisfy their needs to prevent antisocial behaviors and enhance the compliance to laws (Boehm, 2013; Olson \& Stalans, 2001).

\section{PROBATIONERS' PARADOXICAL EXPERIENCES}

It was already proven in the studies that probationers were a marginalized group of people. They are generally labeled as dangerous individuals, which results in their adverse experiences once they were released to the community (Domingo \& Labid, 2016; Evans \& Cubellis 2015; Kilmer, 2016). Their joy and sorrow experiences as being probationers may positively or negatively affect their lives and their rehabilitation in general. For the probationers living within the community, they experienced paradoxical lives that postulate their successful re-entry to the community and desist them from crimes, or it may pull them back to the jail as a result of re-offending, which leads to the revocation of their probation program. These paradoxical lives of probationers are associated with how they view their present situation; the joy and sorrow they experienced helped or pulled them in their situation as they face their challenges (Klingele, 2013; Maruna, 2001; Phelps, 2013; Wagoner, 2010).

The joyful experiences are centered on the contentment and satisfaction of their probation life. This pleasurable feeling has resulted from the satisfaction of their psychological and social needs, such as survival, physiological, relationships, freedom, and security (Carr \& Batlle, 2015; Charles, 2016; Luna, 2013; Sump, 2016). Accordingly, it is important to accomplish these needs to decrease deviant behaviors and increasing the chances of compliance. Olson (2012) cited that happiness is a way of life, and it is an important aspect of human existence. The renowned Buddhist Monk Dalai Lama expressed his idea that the whole purpose of human life is to seek happiness (Joshanloo, 2014). This emotion affects the well-being of a person, which is also associated with their disposition towards their life and to other people. Those probationers, having positive emotions, and supportive families play a crucial role in their attempt to rebuild their lives (Boehm, 2013). Previous studies have already confirmed that family relationship and positive supports are an enviable element in the success of their community-based correction (Farrall \& Calverley, 2005; Hepburn \& Griffin, 2004; Kilmer, 
2016; Mezey, Youngman, Kretzschmar, \& White, 2016; Miller, Copeland, \& Sullivan, 2014; Moore, \& Tangney, 2017; Schneider \& McKim, 2003).

In addition, employment has a similar psychological effect on probationers. The benefits of having legitimate jobs and steady income prevented them from engaging in illicit activities to support their family needs. Hence, Farrall and Calverley (2005) stated that employment also provided them with a sense of self-worth and happiness that someone still trusted their skills and gave them a chance to reform (Domingo \& Labid 2016; Hepburn \& Griffin, 2004; Kilmer, 2016; Naus, 2013; Sensui, 2016). The confidence and trust they feel towards their co-workers and other members of the community are an essential element of the rehabilitation process (Boehm, 2013; Decker, Ortiz, Spohn \& Hedberg, 2015; Young \& Powell, 2015). This happiness, when attained, provides a feeling of self-worth that motivates them to continue to desist from crimes and support the idea that a person needs a sense of fulfillment in their life (Farrall, \& Calverley, 2005; Olson, 2012).

On the other hand, a study has revealed that the real happiness experienced by probationers will start from the moment they are released from jail or prison (Marier \& Reyes, 2014). Despite the fear, stress, anxiety, and other negative feels as a result of their incarceration. Still, most probationers were joyful about leaving the prison. These joyful experiences by probationers are the result of being free from prison life. The report of BY Lanesca (2014) described the real scenarios of the Philippines jail and prison, which characterized by poverty, corruption, and lack of adequate correctional facilities. The inmates experienced contamination of disease due to overcrowding, lack of funds, inadequate food diet, poor sanitation, and ventilation, which affected the process of rehabilitation and other correctional activities. In addition, the multioccupancy type of prison cells and the presence of prison gangs are additional issues that significantly affect the environmental conditions and the process of rehabilitation inside the jail or prison. (Cruzat, Delgado, Magsaysay, Sison, \& Mojares, 2015; Jones, 2014; Narag, and Jones, 2017). This current jail and prison situation in the Philippines will affect the well-being and safety of the inmates, and those potential to become probations' grantees. In consonance with the statement of Bender, Cobbina, and McGarrell (2016), individuals who were previously involved in gangs or have engaged in violence while inside the jail have higher possibilities of committing crimes and drug abuse. These circumstances affect the conditions of ex-offenders, including but not limited to, probationers in their successful integration into the community (Gehring, Van Voorhis, \& Bell, 2010).

The sorrowful experiences of the probationers started when they lose their connectivity to their family, friends, and community are more likely to be influenced and associated by criminals (Eshareturi \& Serrant, 2018; Woldgabreal, Day, \& Ward, 2014). Westerling (2014) cited that the feeling of isolation and failure to connectedness from the community at large of the probationers are more likely to seek companionship and friendships among those who belong to the criminal community. He added that in his study on parolees, probationers, and other ex-offenders cited that their friends were the reasons for their recidivism (Mashek, Stuewig, Furukawa, \& Tangney, 2006). Almost all probationers or anyone who has a taint of imprisonment experienced social stigma and discrimination (Moore \& Tangney, 2017; Turney, Lee, \& Comfort, 2013). Probationers received the stigmatizing label as being a criminal and dangerous person, which sullied their individual's integrity, feeling of inferiority and marginalized their community participation and other social activities. It has interpersonal consequences towards family, friends, and social relationships (Mezey et al., 2016; Moore, 2016). Furthermore, Moore (2016) and Galli (2018) revealed that the social stigma could cause withdrawal from situations which have a negative impact to behavior and functioning and have direct implication for the probationers' rehabilitation and reformation progression. It has adverse effects on their employment or any other activities that may relate to financial opportunity (Ofodile, 2016; Welsh, Knudsen, Knight, Ducharme, Pankow, Urbine, \& Friedmann, 2016). Naus (2013) and Uggen, Vuolo, Lageson, Ruhland, and Whitham's (2014) studies found that prior prison sentence and criminal records stigmatized the person which impeded in gaining successful employment (Chintakrindi, Porter, Kim, \& Gupta, 2015; Emmert, 2015; Miller et al., 2014).

All of these circumstances are due to the social reaction of people towards the individuals' previous incarceration and criminal records. In the book of Siegel (2018), he discussed that social reaction theory depends on the concepts of interaction and interpretation. Marginalized individuals like probationers are variously labeled as they interact with the community. Those people who are labeled negatively diminished their opportunities and affected their confidence towards interaction and relationships with others. Accordingly, the probationers who accepted these labels are prone to engage in deviant behaviors and blunder the purposes of their probation (Emmert, 2015; Siegel, 2018).

The vast existing studies have already confirmed the challenges faced by probationers. However, there is an existing gap of the studies in the Philippine setting in exploring the life of probationers. In addressing the existing gap, the study presented a qualitative data about Filipino probationers' experiences during the period of their probation program.

\section{METHODS}

Data for this study were collected from the 17 probationers in Ozamiz City, Misamis Occidental, located in the northern part of Mindanao. Purposive sampling methods were based on the criteria set on this study. The first criterion pertains to their willingness to participate in the study by signing the informed consent provided before the actual conduct of the interview. Second, the period of sentence under the probation program and last, those 
participants who have married status. For this study, married status participants referred to those probationers who have either martial or non-marital partners, more particularly those who have children. According to Sump (2016), married probationers or those who have common partners have more burden or obligation to support their family. Previous studies have confirmed that family, including parents, spouse, and children were the influential factors in the probationers' rehabilitation process or adversely, pushed to become recidivism (Kilmer, 2016; Mezey et al., 2016; Sump, 2016; Rains-Russell, 2009). Out of 17 participants, ten choose to participate in an in-depth interview and seven for the focus group discussion. The interview using the semi-structured interview guide lasted from 45 minutes to one hour, and all of them were contracted for the second contact to discuss the study findings and to make sure that the study findings reflect their own experiences (Creswell, 2014).

Part of the process, the study passed and obtained a compliance certificate for the study ethics protocol with a serial number of A408-1110-2018. It was examined and evaluated by the University of Mindanao Ethics Review Committee (UMERC) and certified that this study complied with the requirements and, therefore, passed using universally accepted scientific procedures and internally accepted ethical guidelines.

\section{DATA ANALYSIS}

All interviews from in-depth and focus group discussions were audio-recorded, transcribed, stored in computer disks with a secured password, and organized using Colaizzi's descriptive phenomenology. The real names and other identifying characters of the participants, including their families, were purposely kept and considered confidential at all times. In securing the identities and establishing their trust and confidence, coded names were used to represent their participation. Since the data collected were based on the native vernacular, the first move was to translate the interview transcript into the English language for universality.

To analyze the data, it followed the steps of Colaizzi's phenomenological process in extracting themes. For the first step, each transcript was thoroughly read to familiarize and obtain the sense of the entire content. Second steps, the transcript with significant statements were recorded on a separate sheet noting the pages and line numbers. From the identified statements, the meaning was formulated and then sorted into categories and clusters of themes. Then, the researcher developed an exhaustive description by incorporating all the identified themes, followed by shortened the dense statement to capture the fundamental structure of the phenomenon. The final step of the process was to verify and validate the identified core themes through seeking the discussion and review of phenomenological experts (Morrow, Rodriguez, \& King, 2015; Shosha, 2012; Wirihana, Welch, Williamson, Christensen, Bakon, \& Craft, 2018)

\section{RESULTS AND DISCUSSION}

The participants in both in-depth interviews and focus group discussions were asked to narrate, describe, and share their experiences as being probationers. There are significant seven themes that emerged, which grouped into two categories; the first refers to tales of joy and second pertains to tales of sorrow as being a probationer. The first group pertains to the four themes developed from their joyful experiences while serving their probation serves. The second group of themes emerged from their fears, anxieties, and other negative experiences which categorized from their sorrowful experiences such as the stigma of being a probationer, traumatization of children and family, insecurity and anxiety.

\section{TALES OF JOY AS BEING A PROBATIONER}

These are the four themes that emerged from the tales of joy, namely: a new lease on life and freedom, friendship and camaraderie with co-probationers, love and support of family, and; acceptance and understanding of community and co-workers. The themes emerged from the happiness and pleasurable experiences of the probationers while serving their community-based correction. They are positive experiences that enhance their ability to cope with the situation.

\section{NEW LIFE AND FREEDOM}

This theme showed how the participants from both indepth interviews and focus group discussions similarly responded to the questions of their joy experiences as being probationer. They experienced happiness when they received their freedom. However, participants also knew that it is just temporary freedom, but still, they treated their probation program as a chance for a new life. From P-1 to FGD7 (participants code names) all recalled it as the happiest moment of their life.

These are some of their shared statement:

The most important that $I^{\prime}$ am freed from imprisonment, it is so difficult to stay behind bars. The probation grant was the start of new life, my new beginning, and hoping to have a good future... I treated by probation as my new life and my freedom (P-3, line 10-15; P-9, line 14-16; P-10, line 64-70).

I am very happy to have my temporary freedom from jail, and I treated it as my new life because I could now continue my life and can find the money for my family.... I can now continue working to support my four kids and my wife, who is nursing our special child at home. (P-5, line 31-34; FGD-4, line 23).

The hardship that they encountered inside the prison facilities provides them with a sense of relief at the moment they release from jail through the probation program. However, it revealed in their statement that there new life and freedom are not intended for their interest but primarily 
for their family. They offer their new life and freedom for parents, wives, and children. They look at it as a chance that they can again support and supervise the needs of their family, especially their children. This experienced was supported in the various studies that the people around them or the support system are considered as the source of their strength to endure their situation and sufferings (Kilmer, 2016; Sump, 2016; Hill-Megginson, 2015; Olson, 2012).

The majority of the participants are breadwinners, and their worries were diminished when probation was approved and granted there released. The participants were also aware that the grant of probation is not absolute. It means that the freedom they experienced was just temporary. Thus, the need to fulfill and accomplish all the conditions imposed by the court as mandated in RA 10707 amended the PD 968 the probation law of the Philippines. Failure to comply with the condition and rules of the program may result in the revocation of their probation grant and reentry to the jail or prison to serve their remaining sentence.

\section{FRIENDSHIP WITH CO-PROBATIONERS}

Many probationers explain that the relationship they have developed with their co-probationers made them happy, and they enjoyed the companionship as one family. The sorrows and worries they felt and experiences were lessened and eased because of the friendship and camaraderie among them. In the statement of FGD-1, when she came to probation, she felt the warm welcome and belongingness among her co-probationers, including the probation officers, staff, and other people within the group.

After my release and joined, I came to my probation, they welcomed me, and I can feel that I belong. I also have my probation officer, who was very kind to me, like an old friend (FGD-1, line 10-12).

Probationer P-4 and P-10 treated their new friends in the probation as a family. They collaborated, shared sentiment, and reflected their wrongdoing as one family. They revealed that:

I was also happy because I made new friends, and I am happy with the fact that my co-probationers are always willing to respond to my requests. I witness our teamwork and understanding of each other (P-4, line 13-15).

Here in probation, I have good company and friends who are like family to me, with whom you can share your problems. (P-10, line 10-21).

For participants FGD-1, P-4, and P-10, they experienced not only a sense of belongingness within the probation, but having companionship through their newfound friends. They treated their co-probationers as new friends and as family members. In return, they collaborated during activities and sessions, shared their sentiments, and helped each other during times of hardship.
This developed bond among the probationers will create a positive, supportive relationship that benefited them. Thus reduced the level of stress they felt in the community as probationers. The claimed of the participants coincide with the studies of Kilmer (2016) and Sump (2016) that the friendship and bonds developed among the probationers were identified as part of the social support system, which associated with positive reentry experiences by each probationers belonging to that group. The positive reentry refers to the re-integration of the probationers to their different communities (Maloic, 2014; Rains-Russell, 2009; Weisburd, Hasisi, Shoham, Aviv, \& Haviv, 2017).

\section{LOVE AND SUPPORT OF FAMILY}

The love and support from their family forced the probationers to be strong and faced the harsh reality. All probationers mostly relied on the warm support from their family, which in return made them stronger to stand and enabled them to face the harsh reality of being probationers. The probationers P-6, P-2, FGD2, and FGD-3 admitted that the support of their family makes them happy. They stated that:

I am also very thankful to GOD for my family's support (P-6, line 12; P-2, line 12-14).

I am happy that I was given probation that I am out in prison, I can now provide support to my family, and I am so happy that they also supported me (FGD-2, line 18-19).

The support of my family is always there, especially now I have another chance and out in prison (FGD-3, line 36-37).

While Participants P-1, FGD-6 experienced smooth and good family relationships with their family, because of that, the participants received warm support from their family.

But, it is different now, our relationship with my wife and children got better compared when I was not yet in probation. Now, Ifeel their supports (P-1, line 64-67).

I am also thankful for my family, who are always there. My parents and relatives were delighted with my great change. (FGD-6, line 27-30).

They stated that because of the love and support of their family, they were able to establish a good relationship with their family. These experiences supported in the studies of Maloic (2014) and Rains-Russell (2009) supported the result of the data that the role of the family is considered as the most important factor in helping the person to stay out of prison. The study of Sump (2016) confirmed that the quality support provided by the probationers' family is the most important element in the process of rehabilitation, this includes the love, care, time, and emotional support provided by a family. It revealed that the emotional support between the family and probationers would create a bond within them. Thus, it 
provides increasing the feelings of self-worth and capabilities to address society's rejection (Kilmer, 2016; Moore, \& Tangney, 2017; Sensui, 2016; Farrall \& Calverley, 2005).

\section{ACCEPTANCE AND UNDERSTANDING OF COMMUNITY AND CO-WORKERS}

The probationers shared their positive experiences that, despite their wrongdoings and crime committed, there are still people willing to accept and understand them. These people were their neighbors, friends, acquaintances, co-workers, and superiors, who knew and believed that they were good persons. Participants revealed that:

Despite my situation, my neighbors continuously showed me respect (FGD-2, line 20).

I am glad that my co-workers did not treat me differently, especially my manager/supervisor he knew that I am a good and a hardworking person that's why he will not disregard me (P-2, line 12-15; P-7, line 16-22).

I am thankful because I was still accepted by my uncle, I work for him as a meat butcher here in the public market. He allowed me to work even sometimes, I need to skip to report for my probation (P-3, line 16-20, 25-28).

The acceptance and understanding with other people resulted from the social bond between the probationers and their community, which included their neighbors, peers, employers, and co-workers are among the most important elements in the process of rehabilitation and reformation. Both Kilmer (2016) and Sump (2016) proved that the social bond of the probationers is another type of attachment to people other than their immediate family. This social bond is a process of interpersonal connection and relationship to other people, which is considered by the probationers as additional support units in their lives.

Hence, the role of the community plays an important aspect in the successful completion of the probation program. The acceptance and understanding of the community, together with the support of the family, decreased the process of re-offending and increased the desistance to crime (Weisburd et al., 2017; Klingele, 2013). Moreover, having stable employment that provides financial support to their families will strengthen the conviction of the probationers to overcome the challenges they encounter and to continue the process of rehabilitation and reformation (Sensui, 2016; Kilmer, 2016; Domingo \& Labid 2016; Miller et al., 2014; Naus, 2013; Hepburn \& Griffin, 2004).

\section{TALES OF SORROW AS BEING A PROBATIONER}

In the area of sorrowful experiences of probationers in dealing with their probation lives, there were another four themes that emerged from their experiences, namely stigma of being a probationer, traumatization of children/family, and; insecurity and anxiety. These experiences were considered as the consequences of their previously committed crime and incarceration. These negative consequences affected their personal and social lives as they continued living in the community where they belong.

\section{STIGMA OF BEING A PROBATIONER}

This theme was the most common adverse response of the participants when they asked regarding their experiences as being probationers. Every participant felt or experienced the stigma from the crime they committed. Probationers P-6, P-8, and FGD-3 revealed their experiences with tears on their eyes, while FGD-4 shared with a serious voice. Here are their statements.

Yes, I heard many negative comments from my relatives, neighbors, and those who knew me. (P-6, line 2729; FGD-4, line 78-89).

But my husband's relatives who were also our neighbors saw me as a bad person because I am a probationer. In their eyes, I am a sinful person. They wanted to challenge me by backstabbing, saying what kind of woman I am who would be involved in that doings. $(P-8$, line 28-34)

After the probationers were out from jail, the taint of imprisonment will always leave a mark on the eyes of people. It is the social consequence of their criminal records. According to Domingo and Labid (2016), and Emmert (2015) which supported this study that social stigma is a condition whereby the people in the community label an individual with inferiority ways based on particular social status. They emotional expressed that being a probationer placed them in a difficult situation, the community including their relatives, friends, and neighbors or even their acquaintances who knew the situation, labeled them directly without viewing all circumstances of how and why they committed it (Turney, Lee, \& Comfort, 2013; Lamet, Dirkzwager, Denkers, \& Van, 2013; Olson, 2012).

Furthermore, social stigmatization is found predictive of poor adjustment in several aspects of probationers' community lives, as previously revealed in the studies of Galli (2018), Moore and Tangney, (2017), and Wagoner (2010). The studies supported the claim of the participants that the stigma of being a probationer has put a negative consequence to their recovery and rehabilitation. The rejection and discrimination experienced by the probationers can inadvertently cause them to revert to deviant behaviors, which resulted in the revocation of their probation grant and return to jail or prison to serve the remaining or additional sentence. 


\section{TRAUMATIZATION OF CHILDREN/FAMILY}

Traumatization experienced by the participants' families was one of the adverse circumstances that will surely leave a mark, particularly in the eyes of their children. This sad reality and it cannot be denied the horrible experiences of their families during the process of apprehension and imprisonment.

\section{Here are their confided stories:}

My children were the most affected among us. They got traumatized about my situation, especially when I was arrested. Until now, I am so concerned about my two children (my boy \& girl). I am anxious about them because they always act like spies lookout for me in case there are police around that might arrest me. It bothered me a lot $(P$ 2, line 18-28).

My wife was worried about my situation as a probationer. She tends to get panic whenever someone is looking for me because we are in a highly monitored place. Plus, the situation here in Ozamiz City where Police Chief is closely monitoring the Lawis where I live. Honestly, I am worried about these possibilities, and I already had a bad record, I do not want my probation will be revoked because I still have my family to raise (P-2, line 18-30).

The thing that kept me worried and marked on my mind was during the raid and the time that I was arrested by the police. It left a trauma to my children, especially to my nine-year-old child, who is very scared at that time. They saw everything from the knocking of our doors by the police and the moment when I almost got hit by the police asking where my husband is. Even to this day, my children already had a phobia of the police. Every night if they would hear a little noise, they would call me and ask what it is, the fear that police officers would arrest me in any moment linger (P-8, line 36-42).

The trauma experienced by the probationers' families during the process of law enforcement interaction causes psychological distress, which left marks on their minds. This sad reality and it cannot be denied the horror consequence of the crime committed by the probationers. The experienced of P-3, P-2, and P-8 are some of the unpleasant experiences of their family which their children are among the most affected in the process. They confided that even now, causing his children to have phobias to the police and feeling unease whenever they have around. This psychological distress experienced by the family members of the probationers should be appropriately addressed through counseling and therapy. In consonance to the study of Cobbina, Morash, Kashy, \& Smith (2014), the family members and other important people of the ex-offenders, parolees and probationers may experience the adverse effects as the result of their past crimes and conviction.

\section{INSECURITY AND ANXIETY}

These are the emotions felt by every probationer on their quest for a better life. As they have experienced temporary freedom, it always has consequential feelings that they might be imprisoned again. They were afraid of uncertain things or circumstances that might happen to them, such as committing another crime or violating the probation condition set by the court, which leads them in the revocation of their probation grant and returns to the prison. These were some of their statements:

I also had a phobia, although I am already in probation, there might be a possibility that anytime I will be arrested again. (P-8, line 42-44).

I am worried that I might commit a crime again while on probation, so I am anxious of my situation. (P-9, line 37-39).

As of now, the only thing that made me worry most is that there is a possibility that I might commit again another offense during the period of my probation. For example, I may be involved in a traffic accident, and I may hit a person on the road, this instance makes me worry so much. (P-7, line 28-37).

We are anxious if we absent because we need to report every month. What if we get absconded, our probation will be revoked, and we will go back to prison. (FGD-6, line 90-95).

The insecurity and anxiety they experienced are among the issues that they face every day. These intangible circumstances are the result of their daily interaction with other people in the community or the unable fulfillment of their obligation as probationers. The probationers' insecurity and anxiety are the results of their harsh experiences inside the jail (Narag \& Jones, 2017). These feelings gave them stress and worry that they might violate and commit another crime resulting in the revocation of their probation and be sent to jail again (Ouellette, Applegate, \& Vuk, 2017).

The study recognized that ties or attachment of the probationers to their families and other support systems such as their relatives, friends, co-workers, neighbors, or any other significant person identified as a vital element in facing their situation. Their shared statements described that their families are the source and reason for everything, the reason for their sacrifices, hard work, and commitment to change. They faced and embraced the sad reality, lowering their pride and moving on with their lives, primarily not for their own good but for the good of their family. The support they need from their spouse, partners, parents, children, including their co-workers, friends, and community is the most significant element to renew themselves against the wrongdoing they previously committed. The family and other support systems of the probationers should realize that their emotional support 
through positive relationships and constant communication is their strength to endure their unpleasant experiences.

\section{CONCLUSION AND RECOMMENDATION}

Based on the results of the study, the participants, as probationers, faced challenging experiences as they interacted with the community. The joy and sorrow experiences are the result of their struggle to survive in their situation. These people are considered victims of circumstances, and they deserve to be in the communitybased correction through the probation program. All of them have the potential to change and renew their lives. They deserve to be in probation rather than prison, wherein they might be contaminated with those who were incorrigible inmates. Their tales of joyful are signs and path to their successful rehabilitation. However, the sorrow tales of the probationers are the consequences of their previous deviant acts. Recognizing this negative consequence can be interpreted as a good sign of rehabilitation. It indicates that emotion and conscience still present, which helped them to repent their wrongdoings and change for the better.

Furthermore, it suggested that the parents, spouse, or common partners, children, relatives, friends, co-workers, neighbors, or any other important person of the probationers should be included in the probation program. There should be a mutual agreement between the probation officers and these persons that they will be part of the whole process of rehabilitation and reformation of their probationers. Probation Officer should conduct evaluation and dialog with these persons emphasizing their important contribution in the process of probationers' rehabilitation and reformation. It is also appropriate that there should be activities that devoted to enhance or develop the relationship among the probationers' family and other support systems. In the part of the criminal justice, that there should be firmed methods of information drive to all sectors of the community. This method is center on reciprocal responsibility of the community in the area of crime prevention and suppression. The community should be aware of their significant contribution to the success of the probationers. The challenges faced by the probationers will lessen if all support systems will work together to provide a conducive environment to facilitate rehabilitation and reformation.

\section{ACKNOWLEDGMENTS}

The author would like to express his sincere gratitude to the participants of the study for their time and valuable contribution. To the Parole and Probation Administration for allowing the researcher to conduct the study. To the personnel of the Ozamiz City Parole and Probation Office for their constant support and cooperation in the realization of this study.

\section{REFERENCES}

[1]. Archambeau, B. (2011). Factors that contribute to success of probationers: Probation officers' point of view. Thesis. Rochester Institute of Technology. Accessed from http://scholarworks.rit.edu/theses

[2]. Bender, K. A., Cobbina, J. E., \& McGarrell, E. F. (2016). Reentry programming for high-risk offenders: Insights from participants. International journal of offender therapy and comparative criminology, 60(13), https://doi.org/10.1177/0306624X15578204

[3]. Boehm, S. (2013). Exploring the Process of Desistance in Two High-Risk Probation Populations. https://digital.library.txstate.edu/handle/10877/4852

[4]. BY Llanesca, T. P. (2010, Mar 14). Philippine prisons in terrible state-US report. The Manila Times Retrieved from https://search.proquest.com/docview/380966556?acco untid $=149218$

[5]. Capece, J. (2018). The Effects of Probation Stipulations on Employment Outcomes and Feelings of Employability Among Probationers in Rhode Island. https://opencommons.uconn.edu/dissertations/1769

[6]. Carr, S., \& Batlle, I. C. (2015). Attachment theory, neoliberalism, and social conscience. Journal of theoretical and philosophical psychology, 35(3), 160. https://doi.org/10.1037/a0038681

[7]. Charles, C. (2016). An exploration of the lived experiences of divorced individuals through the lens of adult attachment theory (Order No. 10164910). Available from ProQuest Central. (1845017167). Retrieved from https://search.proquest.com/docview/1845017167?acc ountid $=149218$

[8]. Chintakrindi, S., Porter, J., Kim, C., \& Gupta, S. (2015). An Examination of Employment and Earning Outcomes of Probationers with Criminal and Substance Use Histories. SAGE Open, 5 (4). https://doi.org/10.1177/2158244015616662

[9]. Cobbina, J. E., Morash, M., Kashy, D. A., \& Smith, S. W. (2014). Race, neighborhood danger, and coping strategies among female probationers and parolees.

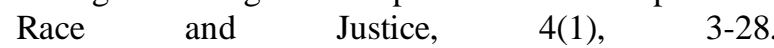
https://doi.org/10.1177/2153368713517397

[10]. Creswell, J.W (2014). Qualitative inquiry and research design. Thousand Oaks, CA: Sage

[11]. Cruzat, M. E., Delgado, B. R., Magsaysay, G. C. A., Sison, L. J. B., \& Mojares, R. (2015). Classification of Inmates in Batangas Provincial Jail, Philippines. Studies in Social Sciences and Humanities, 2(4), 234238. https://bit.ly/3fSnbIx

[12]. Decker, S. H., Ortiz, N., Spohn, C., \& Hedberg, E. (2015). Criminal stigma, race, and ethnicity: The consequences of imprisonment for employment. Journal of Criminal Justice, 43(2), 108-121. https://doi.org/10.1016/j.jcrimjus.2015.02.002 
[13]. Domingo, P. S., \& Labid, S. A. C. (2016). Social Stigma, Stigma Management among Probationers and Parolees of Samar, Philippines. International Journal of Multidisciplinary Approach \& Studies, 3(6). https://bit.ly/3fGSvcS

[14]. Emmert, A. D. (2015). Employment after incarceration: Exploring the influence of cumulative disadvantage on multiple employment outcomes (Order No. 3702540). Available from ProQuest Central. (1685390390). Retrieved from https://search.proquest.com/docview/1685390390?acc ountid $=149218$

[15]. Eshareturi, C., \& Serrant, L. (2018). Challenges and opportunities for ex-offender support through community nursing. International journal of offender therapy and comparative criminology, 62(14), 46424654. https://doi.org/10.1177/0306624X18764854

[16]. Evans, D. N., \& Cubellis, M. A. (2015). Coping with stigma: How registered sex offenders manage their public identities. American Journal of Criminal Justice: AJCJ, 40(3), 593-619. doi: http://dx.doi.org/10.1007/s12103-014-9277-z

[17]. Farrall, S., \& Calverley, A. (2005). Understanding desistance from crime. McGraw-Hill Education (UK). https://bit.ly/30liOiy

[18]. Galli, P. M. (2018). Does family outweigh risk? Corrections Today, 80(1), 16-20,74. Retrieved from https://search.proquest.com/docview/1987359773?acc ountid $=149218$

[19]. Gehring, K., Van Voorhis, P., \& Bell, V. (2010). What works" for female probationers? An evaluation of the Moving On program. Women, Girls, and Criminal Justice, 11(1), 6-10. https://bit.ly/394Zk5G

[20]. Hepburn, J. R., \& Griffin, M. L. (2004). The effect of social bonds on successful adjustment to probation: An event history analysis. Criminal Justice Review, 29(1), 46-75. https://doi.org/10.1177/073401680402900105

[21]. Hill-Megginson, V. (2015). The role of family cohesiveness helping adult female offenders prevent recidivism (Order No. 3728029). Available from ProQuest Central. (1733691767). Retrieved from https://search.proquest.com/docview/1733691767?acc ountid $=149218$

[22]. Jones, C. (2014). Prison gangs and prison governance in the Philippines. Griffith Asia Quarterly, 2(1), 5774. https://bit.ly/3eGAhqO

[23]. Joshanloo, M. (2014). Eastern conceptualizations of happiness: Fundamental differences with western views. Journal of Happiness Studies, 15(2), 475-493. https://link.springer.com/article/10.1007\%2Fs10902013-9431-1

[24]. Kilmer, A. R. (2016). "i'm just trying to fit back in" the role of social bonds, stigma, and legal consciousness on the reentry experiences of recently incarcerated adults (Order No. 10157850). Available from ProQuest Central. (1823281758). Retrieved from https://search.proquest.com/docview/1823281758?acc ountid $=149218$
[25]. Klingele, C. (2013). Rethinking the use of community supervision. Journal of Criminal Law \& Criminology, 103(4), 1015-1069. Retrieved from https://search.proquest.com/docview/1494725057?acc ountid $=149218$

[26]. Lamet, W., Dirkzwager, A., Denkers, A., \& Van, D. L. (2013). Social bonds under supervision: Associating social bonds of probationers with supervision failure. Criminal Justice and Behavior, 40(7), $784 . \quad$ Retrieved from https://search.proquest.com/docview/1365650576?acc ountid $=149218$

[27]. Luna, L. (2013). An exploration of attraction through attachment theory: The influence of attachment style in the selection of a romantic partner (Order No. 3560883). Available from ProQuest Central. (1362256735). Retrieved from https://search.proquest.com/docview/1362256735?acc ountid $=149218$

[28]. Maloic, S. (2014). Modern approaches to sanctioning as determinants of the quality of life in the family, the neighbourhood and the community - new perspectives on reducing crime. Kriminologija \& Socijalna Integracija, 21(2), 45-59. Retrieved from https://search.proquest.com/docview/1505378044?acc ountid $=149218$

[29]. Marier, A. M., \& Reyes, A. A. (2014). Incarceration and Reintegration: How It Impacts Mental Health. https://scholarworks.lib.csusb.edu/etd/26/

[30]. Maruna S (2001) Making Good. How Ex-Convicts Reform and Rebuild Their Lives, American Psychological Association. https://bit.ly/32ucJmv

[31]. Mashek, D., Stuewig, J., Furukawa, E., \& Tangney, J. (2006). PSYCHOLOGICAL AND BEHAVIORAL IMPLICATIONS OF CONNECTEDNESS TO COMMUNITIES WITH OPPOSING VALUES AND BELIEFS. Journal of Social and Clinical Psychology, 25(4), 404-428. doi: http://dx.doi.org/10.1521/jscp.2006.25.4.404

[32]. Mezey, G., Youngman, H., Kretzschmar, I., \& White, S. (2016). Stigma and discrimination in mentally disordered offender patients - a comparison with a non-forensic population. The Journal of Forensic

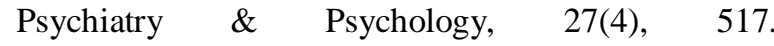
http://dx.doi.org/10.1080/14789949.2016.1172658

[33]. Miller, J., Copeland, K., \& Sullivan, M. L. (2014). How probation officers leverage "third parties" in offender supervision. Journal of Offender Rehabilitation, 53(8), 641. Retrieved from https://search.proquest.com/docview/1628887364?acc ountid $=149218$

[34]. Moore, K. (2016). A longitudinal model of internalized stigma, coping, and post-release adjustment in criminal offenders (Order No. 3720703). Available from ProQuest Central. (1726027359). Retrieved from https://search.proquest.com/docview/1726027359?acc ountid $=149218$ 
[35]. Morrow, R., Rodriguez, A., \& King, N. (2015). Colaizzi's descriptive phenomenological method. The psychologist, 28(8), 643-644.Moore, K. E., \& Tangney, J. P. (2017). Managing the concealable stigma of criminal justice system involvement: A longitudinal examination of anticipated stigma, social withdrawal, and post-release adjustment. Journal of Social Issues, 73(2), 322-340. http://eprints.hud.ac.uk/id/eprint/26984/1/Morrow_et_ al.pdf

[36]. Narag, R. E., \& Jones, C. R. (2017). Understanding prison management in the Philippines: A case for shared governance. The Prison Journal, 97(1), 3-26. https://doi.org/10.1177/0032885516679366

[37]. Naus, T. J. (2013). Measuring evidence-based practices in probation: Does timing of sanctions impact probation termination status (Order No. 3599627). Available from ProQuest Central. (1461742754). Retrieved from https://search.proquest.com/docview/1461742754?acc ountid $=149218$

[38]. Ofodile, R. (2016). Impact of neighborhood opportunity network on recidivism in new york city (Order No. 10182965). Available from ProQuest Central. (1835142416). Retrieved from https://search.proquest.com/docview/1835142416?acc ountid $=149218$

[39]. Olson, D. E., \& Stalans, L. J. (2001). Violent offenders on probation: Profile, sentence and outcome differences among domestic violence and other violent probationers. Violence Against Women, 7(10), 1164-1185. Retrieved from https://search.proquest.com/docview/221559003?acco untid=149218

[40]. Ouellette, H. M., Applegate, B. K., \& Vuk, M. (2017). The Public's stance on prisoner reentry: Policy support and personal acceptance. American Journal of Criminal Justice: AJCJ, 42(4), 768-789. http://dx.doi.org/10.1007/s12103-016-9382-2

[41]. Phelps, M. S. (2013). The paradox of probation: Community supervision in the age of mass incarceration. Law \& Policy, 35(1-2), 51-80. http://dx.doi.org/10.1111/lapo.12002

[42]. Rains-Russell, L. (2009). The role of felony probationers' families in the desistance process (Order No. 3367246). Available from ProQuest Central. (305131151). Retrieved from https://search.proquest.com/docview/305131151?acco untid $=149218$

[43]. Sandoval, J. R. (2020). "Everyone is on supervision": the function of home visits in structuring family dynamics and exerting continuous control. Journal of Offender Rehabilitation, 59(4), 177-197. https://doi.org/10.1080/10509674.2020.1733166

[44]. Schneider, A., \& McKim, W. (2003). Stigmatization among probationers. Journal of Offender Rehabilitation, 38(1), 19-31. Retrieved from https://search.proquest.com/docview/195773000?acco untid $=149218$
[45]. Sensui, L. M. (2016). A study of immediate sanction effectiveness to reduce new conviction post-probation (Order No. 10295947). Available from ProQuest Central. (1846955256). Retrieved from https://search.proquest.com/docview/1846955256?acc ountid $=149218$

[46]. Shosha, G. A. (2012). Employment of Colaizzi's strategy in descriptive phenomenology: A reflection of a researcher. European Scientific Journal, 8(27).Spohr, S. A., Suzuki, S., Marshall, B., Taxman, F. S., \& Walters, S. T. (2016). Social support quality and availability affects risk behaviors in offenders. Health \& Justice, 4(1), 1-10. http://dx.doi.org/10.1186/s40352-016-0033-y

[47]. Sump, K. (2016). Probationers' quality of life based on their perception of sibling relationship (Order No. 10244605). Available from ProQuest Central. (1844973649). Retrieved from https://search.proquest.com/docview/1844973649?acc ountid $=149218$

[48]. Turney, K., Lee, H., \& Comfort, M. (2013). Discrimination and psychological distress among recently released male prisoners. American journal of men's health, 7(6), 482-493. https://doi.org/10.1177/1557988313484056

[49]. Uggen, C., Vuolo, M., Lageson, S., Ruhland, E., \& K. Whitham, H. I. L. A. R. Y. (2014). The edge of stigma: An experimental audit of the effects of lowlevel criminal records on employment. Criminology, 52(4), 627-654. https://doi.org/10.1111/17459125.12051

[50]. Wagoner, S. A. (2010). Perceptions of probationers and their motivation for successful completion of a probation term (Order No. 1479130). Available from ProQuest Central. (734722396). Retrieved from https://search.proquest.com/docview/734722396?acco untid $=149218$

[51]. Weisburd, D., Hasisi, B., Shoham, E., Aviv, G., \& Haviv, N. (2017). Reinforcing the impacts of work release on prisoner recidivism: the importance of integrative interventions. Journal of Experimental Criminology, 13(2), 241-264.

[52]. Welsh, W. N., Knudsen, H. K., Knight, K., Ducharme, L., Pankow, J., Urbine, T., . . . Friedmann, P. D. (2016). Effects of an organizational linkage intervention on inter-organizational service coordination between Probation/Parole agencies and community treatment providers. Administration and Policy in Mental Health and Mental Health Services Research, 43(1), 105-121. doi: http://dx.doi.org/10.1007/s10488-014-0623-8

[53]. Westerling, Thomas W., I.,II. (2014). Community connectedness and terror management theory: Predicting criminogenic cognitions among exoffenders (Order No. 3641450). Available from ProQuest Central. (1627787847). Retrieved from https://search.proquest.com/docview/1627787847?acc ountid $=149218$ 
[54]. Wirihana, L., Welch, A., Williamson, M., Christensen, M., Bakon, S., \& Craft, J. (2018). Using Colaizzi's method of data analysis to explore the experiences of nurse academics teaching on satellite campuses. Nurse Researcher (2014+), 25(4), 30. https://doi:10.7748/nr.2018.e1516

[55]. Woldgabreal, Y., Day, A., \& Ward, T. (2014). The community-based supervision of offenders from a positive psychology perspective. Aggression and Violent Behavior, 19(1), 32-41. https://doi.org/10.1016/j.avb.2013.12.001

[56]. Young, N. C. J., \& Powell, G. N. (2015). Hiring exoffenders: A theoretical model. Human Resource Management Review, 25(3), 298-312. https://doi.org/10.1016/j.hrmr.2014.11.001 